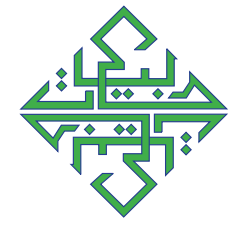

\title{
FAKTOR DEMOTIVASI PEMBELAJARAN BAHASA ARAB DALAM PERSPEKTIF SISWA MADRASAH
}

\author{
Asep Muhammad Saepul Islam \\ Madrasah Aliyah Negeri Tanggeung, Cianjur \\ e-mail : mangamsi@gmail.com
}

Naskah diterima: 18 Februari 2015, direvisi: 12 Maret 2015, disetujui: 20 April 2015.

\begin{abstract}
Motivation plays important role in language learning. When the language learner's motivation is decreasing then he is being in a demotivation stage. Several previous studies in reveal that demotivation could diminish the student achievement in language skill. The phenomenon of this demotivation is rising in Arabic language learning in Indonesia's madrasa. Using qualitative method with short essay from 105 students of Madrasah Aliyah Negeri (MAN) Cianjur, this study shows two major factors that cause demotivation in Arabic learning: external and internal. Specific external factors come from: (1) complexity of Arabic language; (2) learning material and method; (3) learning facility and environment; and (4) teacher's behavior and personality. While internal factor sources are: (1) basic skill and previous learning experience; (2) negative attitude to Arabic subject. These factors need to be considered by teacher and other stakeholder as basic reference to increase student's motivation in Arabic learning.
\end{abstract}

Keywords : learning motivation, demotivation factors, Arabic learning

\begin{abstract}
Abstrak
Motivasi merupakan hal yang penting dalam mempelajari bahasa. Motivasi memiliki kontribusi dalam menumbuhkan minat pebelajar untuk mempelajari suatu Bahasa. Dalam mempelajari bahasa Asing, motivasi berperan sangat penting di samping faktor-faktor lainnya, seperti: usia, gender, lingkungan, dan fasilitas. Artikel ini mendeskripsikan kasus yang terjadi di Madrasah Aliyah Negeri Cianjur, tentang rendahnya motivasi belajar siswa dalam kegiatan belajar mengajar bahasa Arab, meliputi : 1) Kompleksitas bahasa Arab; 2) Materi dan metode; 3) Fasilitas dan sarana belajar; serta 4) faktor Kepribadian Guru. Faktor-faktor ini perlu diperhatikan agar pembelajaran bahasa Arab dapat Menyenangkan dan meningkatkan motivasi siswa.
\end{abstract}

Kata Kunci : motivasi belajar, faktor demotivasi, pembelajaran bahasa Arab

How to Cite : Islam, Asep. "FAKTOR DEMOTIVASI PEMBELAJARAN BAHASA ARAB DALAM PERSPEKTIF SISWA MADRASAH" ARABIYAT : Jurnal Pendidikan Bahasa Arab dan Kebahasaaraban [Online], Volume 2 Number 1 (30 Juni 2015)

Permalink/DOI: http://dx.doi.org/10.15408/a.v2i1.1511 


\section{Pendahuluan}

Motivasi memiliki kontribusi besar dalam menumbuhkan minat pembelajar. Demikian halnya dalam pembelajaran bahasa, motivasi memainkan peranan penting dengan beragam caranya. ${ }^{1}$ Penelitian tentang motivasi pembelajaran bahasa asing tertuju pada apa yang menjadikan seseorang ingin mempelajari bahasa asing dan apa yang menjaganya agar senantiasa termotivasi untuk mempelajari bahasa asing tersebut. Meskipun pada beberapa kasus, peranan motivasi dalam proses belajar bahasa kedua belum dapat dipastikan signifikansinya. $^{2}$

Peranan motivasi dalam mempelajari bahasa asing merupakan masalah yang kompleks, mengingat bahasa selalu terkorelasi dengan konteks sosial dan budaya, dan karena itu sedikit berbeda dari kajian lain. Lebih spesifik lagi, penguasaan bahasa asing juga merupakan peristiwa sosial yang selalu diiringi oleh unsur-unsur kebudayaan dari bahasa asing itu sendiri ${ }^{3}$

Pada umumnya, perhatian penelitian tentang motivasi pembelajaran bahasa asing lebih terfokus pada pengaruh-pengaruh positif yang mendorong ketertarikan belajar bahasa dan upaya untuk memelihara minat tersebut. Padahal, terdapat juga sisi lain motivasi yang mungkin dialami oleh setiap pembelajar. Kondisi tersebut adalah kehilangan motivasi untuk sementara waktu. Keadaan inilah yang kemudian disebut sebagai pengaruh demotivasi.

1 Lihat Robert C. Gardner, "Motivation and Second Language Acquisition," Porta Linguarum 8 (2007), h. 9-20.

2 Abdul Chaer, Psikolinguistik: Kajian Teoretik (Jakarta: Rineka Cipta, 2009), h. 252.

3 Jenni Muhonen, "Second Language Demotivation: Factors That Discourage Pupils From Learning The English Language," tesis di University Of Jyväskylä, 2004, h.5.

\section{Fenomena demotivasi dalam} mempelajari bahasa asing ini muncul di berbagai negara. Di Inggris misalnya, pada November 2013, British Council merilis sebuah laporan tentang fenomena menurunnya motivasi belajar bahasa asing di kalangan orang Inggris. Worne dari British Council mengemukakan bahwa Inggris membutuhkan orang yang menggunakan bahasa baru seperti Arab, Cina dan Jepang. Dari laporan tersebut, temuan yang menarik adalah bahasa Arab dianggap sebagai bahasa kedua yang penting untuk dipelajari oleh warga Inggris setelah bahasa Spanyol ${ }^{4}$

Dari perspektif teoretis, Fakhrurrozi dan Mahyuddin menyatakan bahwa paling tidak ada dua problem yang sedang dan akan terus kitahadapidalampembelajaranbahasaArab, yaitu problem kebahasaan dan problem nonkebahasaan. ${ }^{5}$ Problem nonkebahasaan (musykilât ghair lughawiyyah) yang dimaksud adalah persoalan-persoalan yang tidak terkait langsung dengan bahasa yang dipelajari siswa tetapi ikut berperan bahkan dominan mempengaruhi tingkat kesuksesan dan kegagalan dari pembelajaran bahasa. Diantara problem nonkebahasaan dalam pembelajaran bahasa adalah masalah yang terkait dengan faktor psikologi seperti motivasi (dawâfi') dan minat belajar (muyûll). ${ }^{6}$

Bahasa-bahasa ini dipilih berdasarkan faktor ekonomi, geopolitik, budaya dan pendidikan termasuk kebutuhan bisnis negara Inggris, target perdagangan luar negeri Inggris, prioritas keamanan dan diplomatik, serta prevalensi di internet. (Lihat http://www.britishcouncil.org/organisation/ publications/languages-future (diakses 13 Desember 2013). Untuk laporan selengkapnya, lihat Teresa Tinsley dan Kathryn Board, Languages for the Future: Which Languages the UK Needs Most and Why(British Council, 2013), h. 3.

5 Aziz Fakhrurrozi dan Erta Mahyudin, Pembelajaran Bahasa Arab (Jakarta: Direktorat Jenderal Pendidikan Islam Kementerian Agama, 2012), h.6.

6 Ibid, h.9. 
Rendahnya minat dan motivasi belajar merupakan salah satu tantangan dalam pengembangan pendidikan bahasa Arab. Muhbib menyatakan bahwa faktor penyebab kesulitan belajar bahasa Arab lebih disebabkan faktor psikologis, edukatif dan sosial. ${ }^{7}$ Hal ini didasarkan pada hasil penelitian yang dilakukan oleh Jamsuri Muhammad Syamsuddin dan Mahdi Mas'ud yang menunjukkan bahwa penyebab kesulitan belajar bahasa Arab ternyata bukan sepenuhnya pada substansi atau materi bahasa Arab, melainkan pada ketiadaan minat (100\%), tidak memiliki latar belakang belajar bahasa Arab (87\%), materi/kurikulum perguruan tinggi (83\%), kesulitan memahami materi bahasa Arab (57\%), dan lingkungan kelas yang tidak kondusif (50\%). ${ }^{8}$

Demotivasi telah menjadi fenomena yang sering terjadi dalam pembelajaran bahasa asing. Fenomena rendahnya motivasi belajar bahasa Arab juga terjadi di kalangan madrasah. ${ }^{9}$ Ainin menyebutkan

7 Muhbib Abdul Wahab, Epistemologi dan Metodologi Pembelajaran Bahasa Arab (Jakarta: Lembaga Penelitian UIN Syarif Hidayatullah, 2008), h. 114-115.

$8 \quad$ Ibid, h. 115.

9 Kata madrasah berasal dari bahasa Arab yang berarti tempat atau wahana untuk mengenyam pendidikan. Madrasah di Indonesia merupakan hasil perkembangan modern pendidikan pesantren yang secara historis sudah eksis jauh sebelum Belanda menjajah Indonesia. Lembaga pendidikan Islam yang pertama ada adalah pesantren. Pesantren mendidik para santrinya untuk mendalami ilmu agama. Ketika pemerintah Belanda memerlukan tenaga terampil untuk membantu administrasi pemerintah jajahan di Indonesia, maka diperkenalkanlah jenis pendidikan yang berorientasi pada pekerjaan. Madrasah adalah satuan pendidikan formal dalam binaan Menteri Agama yang menyelenggarakan pendidikan umum dan kejuruan dengan kekhasan agama Islam yang mencakup Raudhatul Athfal, Madrasah Ibtidaiyah, Madrasah Tsanawiyah, dan Madrasah Aliyah. (lihat Direktorat Pendidikan Madrasah Direktorat Jenderal Pendidikan Islam Kementerian Agama RI, Profil Madrasah (Jakarta: Direktorat Pendidikan Madrasah bahwa dalam konteks pembelajaran bahasa Arab di Indonesia, akhir-akhir ini disinyalir sedang terjadi fenomena demotivasi dalam pembelajaran bahasa Arab pada jenjang pendidikan dasar dan menengah, terutama di Madrasah Ibtidaiyah (MI), Tsanawiyah (MTs), dan Madrasah Aliyah (MA). ${ }^{10}$

Fenomena demotivasi merupakan hal yang perlu diperhatikan oleh para praktisi pengajaran. Hal ini menjadi isu yang kompleks dan belum banyak kajian kontemporer yang melakukan pembahasan mengenai ini. ${ }^{11}$ Dalam perspektif psikologis, Ainin menegaskan bahwa jika fenomena demotivasi dibiarkan, maka pembelajaran bahasa Arab pada jenjang pendidikan dasar dan menengah, terutama di MI, MTs, dan MA akan tinggal nama tanpa makna. Padahal dalam konteks pendidikan di madrasah yang berbasis pada nilai-nilai keislaman, seharusnya mata pelajaran bahasa Arab menjadi mata pelajaran utama dalam mencapai visi dan misi madrasah. ${ }^{12}$

Penelitian ini dimaksudkan untuk mengkaji faktor demotivasi pembelajaran bahasa Arab yang disinyalir tengah terjadi di madrasah. Hal ini dipandang perlu karena bahasa Arab di madrasah merupakan salah satu mata pelajaran wajib sekaligus kemampuan dasar yang harus dimiliki seorang pembelajar untuk memahami kajian-kajian keislaman pada tingkatan

Direktorat Jenderal Pendidikan Islam Kementerian Agama RI, 2014), h. 8-13; Peraturan Menteri Agama Republik Indonesia Nomor 90 Tahun 2013 tentang Penyelenggaraan Pendidikan Madrasah).

10 Moch. Ainin, Fenomena Demotivasi dalam Pembelajaran Bahasa Arab di Madrasah: Penyebab dan Alternatif Pemecahannya, pidato pengukuhan guru besar sebagai Guru Besar dalam bidang Pembelajaran Bahasa Arab pada Fakultas Sastra (FS) Universitas Malang (UM), Kamis, 28 April 2011, h. 3.

11 Omid Tabatabaei dan Ahmad Molavi, "Demotivating Factors Affecting EFL Learning of Iranian Seminary Students." International Education Studies Vol. 5, No. 1 (2012), h. 186.

12 Ainin, op.cit., h.3. 
selanjutnya dan juga sebagai bahasa pergaulan internasional.

\section{Kajian Pustaka dan Riset Terdahulu}

Dörnyei dan Ushioda mendefiiniskan demotivasi sebagai sejumlah pengaruh negatif yang dapat menggagalkan motivasi yang sedang tumbuh. ${ }^{13}$ Seorang pembelajar yang terdemotivasi adalah seseorang yang pernah termotivasi namun kemudian kehilangan komitmen atau minat belajarnya dikarenakan beberapa alasan. Kegagalan pembelajaran bahasa asing merupakan fenomena yang sering muncul dan studi tentang penyebab-penyebabnya sering dikaitkan dengan demotivasi. ${ }^{14}$

Beberapa riset tentang demotivasi telah dilakukan di berbagai negara, terutama di Eropa, Amerika, dan Asia. Di Hungaria misalnya, dengan menggunakan wawancara terstruktur terhadap 50 orang siswa sekolah menengah yang diduga sedang terdemotivasi, Dörnyei menemukan beberapa faktor. Faktor-faktor tersebut antara lain meliputi faktor guru, fasilitas sekolah, kurangnyapercaya diri,sikapnegatif terhadap bahasa asing dan komunitasnya, kewajiban mempelajari bahasa asing, sikap kelompok, dan juga buku ajar yang digunakan dalam kelas. ${ }^{15}$

Riset Dornyei ini mengilhami penelitian-penelitian selanjutnya tentang demotivasi dalam pembelajaran bahasa asing. Di Jepang, Falout dan Maruyama merancang kuesioner berdasarkan faktorfaktor demotivasi yang dikemukakan oleh Dörnyei. Keduanya menyimpulkan adanya perbedaan faktor penyebab demotivasi antara pembelajar bahasa Inggris dengan

\footnotetext{
13 Zoltan Dörnyei dan Ema Ushioda, Teaching and Researching Motivation (2nd ed.), (Harlow, England: New York, Longman, 2011), h. 139.

14 Ibid., h.142.

15 Ibid., h.150-155.
}

tingkat kemahiran yang tinggi dibanding dengan pembelajar dengan tingkat kemahiran yang rendah. Pada pembelajar dengan kemampuan rendah, faktor internal seperti kurangnya kepercayaan diri lebih dominan dalam menyebabkan munculnya demotivasi. ${ }^{16}$

Dalam riset lainnya di Jepang, Hamada dan Kito juga menemukan lima faktor demotivasi dalam pembelajaran bahasa asing yaitu lingkungan belajar, gaya dan kompetensi guru, rendahnya motivasi intrinsik, metode pengajaran yang tidak komunikatif dan bahan ajar. ${ }^{17}$ Masih di Jepang, Kikuchi dan Sakai mengidentifikasi lima faktor demotivasi yaitu bahan ajar, kompetensi dan gaya guru, fasilitas sekolah yang kurang memadai, kurangnya motivasi intrinsik dan skor tes. ${ }^{18}$ Sementara itu melalui risetnya di Taiwan pada 2013, Chen menyebutkan bahwa faktor internal yang didominasi oleh kurangnya kepercayaan diri menjadi pemicu utama dalam munculnya demotivasi dalam pembelajaran bahasa asing, khususnya bahasa Inggris. ${ }^{19}$

Khusus mengenai demotivasi pembelajaran bahasa Arab, Aladdin melakukan riset tentang faktor demotivasi mahasiswa nonmuslim yang belajar bahasa Arab di Malaysia. Dari penelitiannya ia menemukan sembilan faktor demotivasi, masing-masing adalah: (1) karakter bahasa

16 Joseph Falout dan Mika Maruyama. "A Comparative Study of Proficiency and Learner Demotivation." The Language Teacher, 28(2004), h. 3-9.

17 Yo Hamada dan Kazuya Kito, "Demotivation in Japanese high schools" in K.Bradford-Watts (Ed.), JALT 2007 Conference Proceeding, (2008), h. 168-178.

18 Keita Kikuchi dan Hideki Sakai, "Japanese Learners' Demotivation to Study English: A Survey Study."JALT Journal Vol. 31, No. 2 (2009), h. 183-204

19 Pin Yu Chen, "An Analysis of Demotivating Factors among EFL High School Students in Central Taiwan," tesis di Chaoyang University of Technology, 2013, h. 36. 
Arab itu sendiri, (2) guru, (3) lingkungan kelas, (4) sikap negatif terhadap bahasa asing, (5) bahan ajar, (6) kewajiban mempelajari bahasa Arab, (7) durasi waktu, (8) kurangnya kesempatan untuk berkomunikasi dalam bahasa Arab, dan (9) kurangnya kemampuan berbahasa. ${ }^{20}$

\section{Metode}

Metode yang digunakan dalam penelitian ini adalah metode kualitatif interaktif. ${ }^{21}$ Studi kasus dipilih sebagai jenis dari metode kualitatif interaktif ini. ${ }^{22} \mathrm{Hal}$ ini dikarenakan tema demotivasi masih menjadi hal yang baru dalam ranah penelitian dan juga faktor ketersediaan teori yang belum lengkap. Tujuan dari metode kualitatif ini adalah untuk menemukan informasi deskriptif tentang faktor penyebab demotivasi.

Data yang merupakan sumber utama bagi penelitian ini adalah para siswa sebagai pembelajar bahasa Arab di Madrasah Aliyah Negeri Cianjur, Kabupaten Cianjur, Jawa Barat. Siswa yang dijadikan partisipan merupakan siswa kelas XI dari tiga program peminatan: IPA, IPS, dan Bahasa. Alasan dijadikannya siswa kelas XI sebagai informan dalam penelitian ini dikarenakan mereka sudah pernah mengalami proses pembelajaran bahasa

20 Ashinida Aladdin, "Demotivating Factors in the Arabic Language Clasroom: What demotivates non-Muslim Malaysian learners when it comes to learning Arabic?" Procedia - Social and Behavioral Sciences 93 (2013), h. 1652 - 1657.

21 Penelitian kualitatif adalah penelitian yang ditujukan untuk mendeskripsikan dan menganalisis fenomena, peristiwa, aktivitas sosial, sikap, kepercayaan, persepsi, pemikiran orang secara individual maupun kelompok. Lihat Nana Syaodih Sukmadinata, Metode Penelitian Pendidikan (Bandung: Remaja Rosdakarya, 2005), h. 60.

22 Studi kasus adalah suatu penelitian yang diarahkan untuk menghimpun data, mengambil penelitian makna, dan memperoleh pemahaman dari kasus tersebut. (ibid., h. 64.)
Arab pada tahun sebelumnya di kelas $\mathrm{X}$, sehingga bisa membandingkan proses pembelajaran di tingkat sebelumnya dengan yang sekarang.

Teknik pengumpulan data yang digunakan untuk penelitian ini adalah dengan menggunakan kuesioner terbuka berupa esei singkat dan juga wawancara. Pengisian esei ini dilakukan dengan cara meminta siswa menuliskan catatan singkat mengenai faktor yang dapat menyebabkan munculnya demotivasi dalam pembelajaran bahasa Arab di kalangan siswa.

Pengisian esai ini melibatkan partisipasi 105 orang siswa dari siswa kelas XI Madrasah Aliyah Negeri Cianjur. Sebanyak 40 partisipan berasal dari siswa kelas XI IPA, 42 orang dari kelas XI IPS dan 23 orang siswa kelas Bahasa. Sementara itu, wawancara dilakukan dengan empat orang siswa yang mewakili masing-masing program peminatan, guru bahasa Arab, kepala sekolah, dan orang tua siswa.

Dalam penelitian ini, data yang diperoleh dari hasil esai singkat dianalisis dan disajikan dalam bentuk uraian. Untuk esei singkat ini, penulis mentabulasikan pernyataan-pernyataan yang dikemukakan oleh siswa partisipan kemudian dianalisis berdasarkan konten pernyataan. Hasil tabulasi ini kemudian dianalisis berdasarkan faktor-faktor demotivasi dalam pembelajaran bahasa asing.

Selanjutnya, data hasil tabulasi tersebut dikategorisasi berdasarkan frekuensi pernyataan yang dikemukakan sehingga menghasilkan gambaran umum faktor demotivasi siswa berdasarkan catatan singkat partisipan. Demikian juga dengan hasil wawancara, data dikontekstualisasikan dalam dua faktor demotivasi pembelajaran bahasa Arab yaitu faktor eksternal dan faktor internal. 


\section{Faktor Eksternal Demotivasi}

\section{Kompleksitas Bahasa Arab}

Dari laporan yang dirilis oleh The Foreign Service Institute (FSI), diperoleh data bahwa bahasa Arab termasuk bahasa yang sulit dipelajari oleh para penutur bahasa Inggris. ${ }^{23}$ Bahasa Arab dikategorikan dalam satu kelas dengan bahasa Mandarin, Kanton, Jepang dan Korea. ${ }^{24}$ Hal ini memperkuat temuan Thomas Irving yang menunjukkan beberapa letak kesulitan dalam belajar bahasa Arab. Di antara kesulitan itu banyaknya sistem bunyi yang berbeda dengan bahasa lainnya, termasuk bahasa Indo-Eropa. Kesulitan berikutnya terletak pada kompleksitas sistem derivasi (isytiqâq). Selanjutnya, banyaknya perubahan bentuk kata dan juga banyaknya kosa kata yang perlu dikuasai dalam proses pembelajarannya. ${ }^{25}$

Dari esai singkat tentang faktor pe-nyebab terjadinya demotivasi yang dikemukakan oleh para siswa di madrasah yang diteliti, karakteristik bahasa Arab menempati urutan pertama dengan

${ }^{23}$ The Foreign Service Institute (FSI), sebuah divisi dalam Department of State Amerika Serikat, mengompilasi prediksi belajar bahasa berdasarkan lamanya waktu yang biasanya dibutuhkan untuk mencapai kemampuan berbicara level 3 (S3) dan General Professional Proficiency in Reading (R3) bagi penutur bahasa Inggris. Perlu diketahui kategorisasi ini terbatas hanya pada bahasa yang diajarkan di Foreign Service Institute (http://www. effectivelanguagelearning.com/language-guide/ language-difficulty), diakses 24 April 2015).

24 Kategori 4 membutuhkan 88 minggu atau setara dengan 2200 jam pelajaran. Bahasa-bahasa ini memang dikenal sangat sulit dipelajari oleh para penutur berbahasa Inggris. Lima bahasa dimaksud adalah: bahasa Arab, Kanton, Mandarin, Jepang dan Korea. Dari kelima bahasa ini, faktor utama sulitnya pembelajaran terletak pada sistem penulisan. (http://aboutworldlanguages.com/languagedifficulty diakses tanggal 24 April 2015)

25 Lihat Irving Thomas, "How Hard is Arabic" The Modern Language Journal, Vol 41, No.6 Oktober 1957. persentase sebesar $49,6 \%$ dari total respon yang berhasil dihimpun dan ditabulasi. Di antara pernyataan partisipan yang menguatkan bahwa karakteristik bahasa Arab menjadi salah satu pemicu munculnya demotivasi dalam mempelajari bahasa Arab lain sebagai berikut, "Jujur, saya tidak menyukai bahasa Arab karena banyak kosakatanya dan bahasa Arab itu seperti matematika yang banyak rumusnya...." ${ }^{26}$

Ungkapan senada bisa kita temukan dalam pernyataan lainnya, misalnya dari pernyataan salah seorang siswa, "Saya tidak terlalu menyukai pelajaran bahasa Arab karena banyak kosakata yang harus dihafalkan dan suka bingung jika ada katakata yang memiliki banyak arti dan membuat saya bingung." ${ }^{27}$

Jika indikator yang paling dominan dari faktor karakterisik bahasa Arab dirinci, maka pernyataan tentang terlalu banyaknya kosa kata yang dihafal begitu sering terlontar dari siswa. Indikator ini berkontribusi sebesar $23,9 \%$ dari total pernyataan yang muncul. Kesulitan lainnya ditimbulkan oleh tata bahasa yang rumit (11,5\%), kebingungan menerjemahkan kata dalam teks $(8,9 \%)$, pengucapan huruf yang sukar $(3,5 \%)$ dan kesulitan mempraktikkan percakapan $(1,8 \%))^{28}$

Hasil pengolahan data ini memperkuat temuan Aladdin yang menyebutkan bahwa secara umum kompleksitas karakteristik bahasa Arab menjadi faktor demotivasi ketika hal tersebut dihadapi oleh pembelajar bahasa Arab. $^{29}$ Temuan ini juga relevan dengan hasil penelitian Zouhir

26 Esei singkat siswa kelas XI IPA, nomor partisipan 029.

27 Esei singkat siswa kelas XI IPS, nomor partisipan 059 .

28 Lihat lampiran "Analisis Esei Singkat Partisipan".

29 Aladdin, op.cit., 1655. 
sebagaimana dikutip Aladdin yang menyatakan bahwa karakteristik bahasa Arab memang kompleks dan rumit sehingga menimbulkan tantangan serius bagi para pembelajarnya. ${ }^{30}$

\section{Fasilitas dan Lingkungan Belajar}

Beberapa studi terdahulu menunjukkan bahwa teman sekelas dan fasilitas sekolah yang kurang memadai dapat menjadi salah satu faktor demotivasi siswa dalam mempelajari bahasa asing. Hamada dan Kito misalnya memasukkan lingkungan belajar dalam daftar penyebab demotivasi pada diri siswa. ${ }^{31}$ Demikian juga dengan hasil temuan Tsuchiya yang dikutip Hamada dan Grafstrom yang menyebutkan bahwa sikap teman sekelas termasuk ke dalam komponen lingkungan belajar yang jika kondisinya negatif dapat memicu munculnya demotivasi. ${ }^{32}$ Sementara itu, Fahrurrozi dan Mahyuddin menyatakan bahwa masalah ketersediaan sarana prasarana, media dan sumber belajar merupakan problem nonkebahasaan yang lazim ditemukan dalam proses pembelajaran bahasa. ${ }^{33}$

Dari esei singkat yang dikemukakan siswa, sebesar 15,9\% faktor demotivasi pembelajaran bahasa Arab berasal dari lingkungan dan fasilitas belajar sekaligus menempati urutan ketiga dari seluruh faktor yang ditabulasi. ${ }^{34}$ Indikator yang sering muncul dalam pernyataan siswa adalah waktu pelajaran yang tidak sesuai $(10,6 \%)$,

\footnotetext{
30 Aladdin, loc.cit.

31 Yo Hamada dan Kazuya Kito, "Demotivation in Japanese high schools" in K.Bradford-Watts (Ed.), JALT 2007 Conference Proceeding, (2008): 168-178.

32 YoHamadadanBenGrafstrom, “Demotivating factors in learning Japanese as a foreign language (Akita University, 2014), h. 11.

33 Aziz Fahrurrozi dan Erta Mahyuddin, Teknik Pembelajaran Bahasa Arab (Bandung: Pustaka Cendekia, 2013), h.11-12.

34 Lihat lampiran "Analisis Esei Singkat Partis pan."
}

perilaku teman yang mengganggu $(3,5 \%)$ dan jumlah rombel yang banyak $(1,8 \%)$.

Pernyataan-pernyataan yang mendukung temuan di atas antara lain sebagai berikut, "Saya tidak suka pelajaran bahasa Arab karena pembelajarannya dilaksanakan pada jam terakhir, sehingga sudah tidak berkonsentrasi padahal saya ingin sekali bisa memahami bahasa Arab."35 Mengenai waktu dan jadwal mata pelajaran yang kurang memadai, pernyataan berikut menggambarkan hal tersebut, "Waktu kegiatan belajar yang terlalu akhir (pelajaran terakhir) membuat saya bosan, mengantuk dan tidak fokus. Dari awal belajar, saya sangat tidak mengerti bahasa Arab dan waktu kelas X, guru yang mengajar cara menjelaskannya tidak sesuai dengan yang saya inginkan."36

\section{Metode Pembelajaran dan Bahan Ajar}

Bahan ajar dan metode pembelajaran dapat menyebabkan demotivasi dalam beragam cara. Kurangnya penggunaan media pembelajaran berbasis multimedia juga dapat menjadi salah satu pemicu munculnya demotivasi siswa dalam mempelajari bahasa Arab. Lubis mengemukakan bahwa penggunaan teknologi infromasi dan komunikasi sangat penting dalam mengajarkan bahasa Arab, sehingga materi dan bahan ajar menjadi lebih mudah dipahami, memberikan pengalaman lebih bagi para siswa dan memungkinkan mereka untuk memperoleh informasi dengan mudah dan pada waktu yang sama tujuan pengajaran dan pembelajaran bahasa Arab di kelas dapat tercapai. ${ }^{37}$

35 Esei singkat siswa kelas XI IPA, nomor partisipan 007.

36 Esei singkat siswa kelas XI IPA, nomor partisipan 010 .

37 Maimun Aqsha Lubis, "Teaching and Learning Arabic Language through Multicultural Approach and Applying ICT in Pesantren Institution," 
Sementara itu, Nasution menyatakan bahwa penggunaan sebuah metode dalam proses pembelajaran bahasa Arab sangat tergantung dari prinsip dan konsep yang dipahami oleh seorang guru atau tenaga pendidik terhadap bahasa. Di samping itu juga sangat erat kaitannya dengan aspek-aspek pembelajaran lainnya. Baik metode konvensional (tradisional) maupun inkonvensional (modern atau inovatif), keduanya memiliki kelebihan dan kekurangan. Untuk itu, seorang tenaga pengajar bahasa Arab harus jeli melihat aspek positif dan negatif dari kedua metode tersebut. $^{38}$

Lebih lanjut Nasution mendefinisikan metode mengajarkonvensional (tradisional) sebagai metode mengajar yang lazim dipakai oleh guru. Sedangkan metode inkonvensional atau modern adalah suatu metode mengajar yang baru berkembang dan belum lazim digunakan secara umum, masih merupakan metode yang baru dikembangkan dan diterapkan di beberapa sekolah tertentu yang mempunyai peralatan dan media yang lengkap serta guru-guru yang ahli menanganinya. ${ }^{39}$

Terkait dengan bahan ajar, H.D. Hidayat menyatakan bahwa peranan bahan ajar dalam metode pengajaran bahasa akan merefleksikan penentuan hal-hal yang berkaitan dengan tujuan utama, bentuk bahan ajar, pertalian bahan ajar dengan sumber masukan bahasa lainnya, dan kemampuan pengajar. ${ }^{40} \mathrm{Hal}$ ini diperkuat oleh pernyataan Fakhrurrozi bahwa keInternational Journal of Education and Information Technologies, Issue 3, Volume 3, 2009, .

38 Sahkholid Nasution, "Metode Konvensional dan Inkonvensional dalam Pembelajaran Bahasa Arab," Jurnal Ilmiah DIDAKTIKA Februari 2012 VOL. XII NO. 2, 259-271.

39 Ibid., h. 263.

40 D. Hidayat, "Pengantar" dalam Aziz Fahrurrozi dan Erta Mahyuddin, Teknik Pembelajaran Bahasa Arab, h. xviii tidaktepatan dan stagnasi pengajar bahasa Arab dalam memilih metode pembelajaran menjadi salah satu problem nonkebahasaan dalam pembelajaran bahasa. ${ }^{41}$

Mengenai belajar kelompok dalam bahasa asing, Naoko Taguchi dalam penelitiannya menyebutkan bahwa dalam dua kelompok belajar yang diteliti, akurasi dan kecepatan pemahaman meningkat signifikan dari waktu ke waktu. Bagi kelompok pembelajar bahasa Inggris sebagai bahasa asing, efek dari kecepatan lebih lemah dibandingkan dengan akurasi. Sementara itu, para pembelajar bahasa Inggris sebagai bahasa kedua menunjukkan perkembangan yang signifikan dalam kecepatan pemahaman dengan dampakyang cukup besar, namun sedikit perkembangan dalam hal akurasi. ${ }^{42}$

Dari esei singkat para siswa di dua madrasah yang diteliti terkait indikatorindikator metode pengajaran dan materi pelajaran yang dapat menurunkan motivasi mereka dalam mempelajari bahasa Arab, diperoleh informasi bahwa

$41 \quad$ Fakhrurrozi dan Mahyuddin, op.cit.,12.

42 Riset ini menguji peranan lingkungan dalam pengembangan pemahaman pragmatik. Riset ini meneliti dua kelompok pelajar Jepang yang mempelajari bahasa Inggris. Enam puluh orang partisipan merupakan para mahasiswa di sebuah perguruan tinggi di Jepang (pembelajar bahasa Inggris sebagai bahasa asing) dan 57 orang partisipan merupakan para mahasiswa di sebuah perguruan tinggi di Amerika (pembelajar bahasa Inggris sebagai bahasa kedua). Para pembelajar melengkapi tugas listening (menyimak) yang sudah dikomputerisasi untuk mengukur kemampuan mereka dalam memahami dua jenis makna implisit. Tugas ini diberikan dua kali untuk masing-masing grup, sebelum dan sesudah siswa menerima kurang lebih 120-130 jam instruksi di kelas. Pemahaman menyimak dianalisis dari segi akurasi (skor) dan kecepatan (rata-rata waktu yang digunakan untuk menjawab setiap butir soal secara benar). (Lihat Naoko Taguchi, "The Role of Learning Environment in The Development of Pragmatic Comprehension: A Comparison of Gains Between EFL and ESL Learners," SSLA, 30, 2008, 423-452 ) 
cara penyampaian materi oleh guru menjadi sorotan siswa. Hal ini tergambar dari pernyataan-pernyataan berikut ini, "Memang saya dulu pernah masuk pesantren yang mewajibkan berbahasa Arab dan pembelajarannya pun bagus karena mencakup semua seperti nahwu, sharaf, dan lain-lain tetapi setelah di sini belajar bahasa Arabnya tanpa dasar jadi langsung, karena itu saya selalu bingung akan belajar bahasa Arab dan susah memahami." ${ }^{43}$

Dari analisis esei singkat siswa, faktor metodologi dan materi pembelajaran menempati urutan keempat penyebab demotivasi siswa. Sebanyak 9,7\% pernyataan siswa menggambarkan indikatorindikator metodologi dan materi pembelajaran. Indikator tersebut terkait dengan metode pembelajaran yang monoton $(8,9 \%)$ dan kurangnya kerja kelompok $(0,8 \%) \cdot{ }^{44}$

Mencermati fenomena pengajaran
bahasa Arab, Yaakub menyatakan
bahwa tantangan pendidikan modern mengharuskan studi Islam dan bahasa Arab lebih komprehensif dan konstruktif. Dalam kondisi seperti inilah, pendekatan dan metodologi harus selalu diperbaharui dan senantiasa dinamis dalam mengantisipasi perkembangan masyarakat modern yang begitu pesat. ${ }^{45}$

Terkait hal di atas, guru bahasa Arab dituntut lebih kreatif dan inovatif dalam meyakinkan kepada anak bahwa mempelajari bahasa Arab itu mudah. ${ }^{46}$ Metodologi pembelajaran bahasa Arab yang berkembang saat ini harus selalu

43 Esei siswa kelas XI IPS 2, nomor 046

44 Lihat lampiran "Analisis Esei Singkat Partisipan."

45 Muhamadul Bakir Hj. Yaakub, "A field observation on the philosophy of teaching Islamic and Arabic studies," US-China Education Review Mar. 2009, Volume 6, No.3 (Serial No.52), h. 40.

46 Wawancara dengan guru bahasa Arab MAN Cianjur, 10 Februari 2015. direlevansikan dengan tuntutan zaman. Lebih lanjut, Kikuchi sebagaimana dikutip Aladdin menegaskan bahwa guru sebaiknya menghindari pendekatan terjemah dan tata bahasa dalam pengajaran bahasa asing, karena pendekatan ini secara umum tidak memberikan ruang pada siswa untuk melakukanperubahan dalamberkomunikasi dengan bahasa asing. ${ }^{47}$

\section{Guru Sebagai Pemicu Demotivasi}

Dalam penelitian terdahulu, demotivasi sering dianggap sebagai hal yang menjadi tanggung jawab guru. Hal ini sebagaimana dinyatakan oleh studi yang dilakukan oleh Christophel dan Gorham, Hasegawa, Falout dan Murayama. Lebih spesifik lagi, Hamada dan Grafstrom mengutip Dornyei menyebutkan bahwa kepribadian guru, komitmen, kompetensi dan metode pengajaran dapat menyebabkan demotivasi dalam diri siswa. ${ }^{48}$ Krashen, sebagaimana dikutip Aladdin, menyatakan bahwa guru bahasa yang efektif adalah seseorang yang mampu memberikan masukan dan menjadikan bahasa lebih mudah dipahami dalam situasi dengan tingkat kecemasan yang rendah. ${ }^{49}$

Kurangnya motivasi dapat menyebabkan guru kurang berhasil dalam mengajarkan bahasa asing. Fattash dalam penelitiannya menemukan bahwa tuntutan administrasi yang berat, rekan kerja yang tidak mendukung, penghargaan yang kurang dan masalah finansial merupakan hal-hal yang dapat menimbulkan demotivasi guru dalam mengajar. Lebih lanjut Fattash menjelaskan bahwa kelelahan, kurangnya minatmengajar dan menuntaskan tugas, emosi yang lemah, dan ketidakpuasan seorang guru akan mempengaruhi performa dan prestasi guru

\footnotetext{
47 Aladdin, op.cit., h. 1656.

48 Hamada dan Grafstrom, op.cit., h. 10.

49 Aladdin, op.cit., h.1655.
} 
tersebut. $^{50}$

Terkait dengan perilaku dan kepribadian guru, Trang dan Baldauf sebagaimana dikutip Sugino menyatakan bahwa perubahan dalam pengajaran dan kurikulum dapat membantu siswa meningkatkan peluang keberhasilannya dalam belajar bahasa asing. Hal ini memperkuat temuan Keblawi yang menyebutkan bahwa faktor yang berkaitan dengan konteks pembelajaran secara langsung seperi guru, kelompok belajar dan buku teks dapat menimbulkan demotivasi jika siswa mempersepsikan hal-hal tersebut dengan negatif. ${ }^{51}$

Perilaku dan kepribadian guru menjadi faktor yang paling jarang ditemukan dalam pernyataan siswa, sehingga faktor ini bisa dikatakan tidak dominan. Hanya tiga pernyataan yang memuat indikator perilaku dan kepribadian guru sebagai pemicu demotivasi siswa. Pernyataan yang mengindikasikan bahwa faktor perilaku dan kepribadian guru dapat menjadi pemicu munculnya demotivasi dapat dicermati pada paparan berikut ini, "Saya tidak terlalu suka bahasa Arab karena waktu pembelajaran terlalu siang, guru selalu memperhatikan murid yang jago bahasa Arab." 52

Dari analisis esei siswa terkait faktor ini, sikap pilih kasih dan tidak bersemangat dalam mengajar menjadi dua hal yang muncul dalam pernyataan sebagian siswa. Sikap pilih kasih berkontribusi sebesar $1,8 \%$ dari total pernyataan dan tidak bersemangat dalam mengajar dinyatakan oleh $0,9 \%$ siswa. Hal ini menempatkan

50 Maher M. Fattash, "Demotivating Factors of University ESL Teachers," International Journal of Humanities and Social Science Vol. 3 No. 19; November 2013,125.

51 Toshiko Sugino, "Teacher demotivational factors in the Japanese language teaching context," Procedia Social and Behavioral Sciences 3 (2010), 216-226.

52 Esei singkat siswa kelas XI IPA, nomor partisipan 017. faktor perilaku dan kepribadian guru menjadi faktor dengan urutan keenam dalam menyebabkan demotivasi dalam pembelajaran bahasa Arab. ${ }^{53}$

\section{Faktor Internal Demotivasi}

\section{Kemampuan Dasar dan Pengalaman Belajar}

Dalam belajar bahasa asing, kemampuan dasar berbahasa mutlak diperlukan sebagai pijakan awal mengembangkan keterampilan berbahasa. Pengalaman belajar bahasa yang dimiliki siswa di jenjang sebelumnya juga berdampak pada keterampilan berbahasa siswa di madrasah. Apalagi materi bahasa Arab pada Madrasah Aliyah merupakan kelanjutan dari jenjang sebelumnya yaitu Madrasah Tsanawiyah. Masalahnya, tidak semua siswa yang masuk Madrasah Aliyah adalah lulusan Madrasah Tsanawiyah sehingga untuk pembelajaran mata pelajaran keagamaan dan bahasa Arab, sebagian siswa mengalami kendala.

Di Madrasah Aliyah yang menjadi lokasi penelitian, input siswa yang mendaftar di kelas X tidak lagi dominan berasal dari MTs. Di MAN Cianjur ini, sekitar 60\% siswa baru pada tiap tahunnya berasal dari SMP. $^{54}$ Hal ini diperkuat oleh pernyataan orang tua siswa yang menyebutkan bahwa pengalaman belajar sebelumnya berdampak besar pada minat dan motivasi anaknya dalam mempelajari bahasa Arab. ${ }^{55}$ Belum lagi preferensi anak dalam memilih bahasa asing selain bahasa Arab juga menyebabkan anak kurang termotivasi dalam mempelajari bahasa Arab.

\footnotetext{
53 Lihat lampiran "Analisis Esei Singkat Partis pan."

54 Wawancara dengan guru bahasa Arab MAN Cianjur, 10 Februari 2015 dan Kepala MAN Cianjur tanggal 20 Februari 2015.

55 Wawancara dengan orang tua siswa, 5 Maret 2015.
} 
Terkait dengan pengalaman belajar, TaeYoung Kim danYoon-Kyoung Kim melakukan riset di Korea Selatan untuk meneliti faktorfaktor yang mendorong dan menghambat pembelajar dalam kelas bahasa Inggris. Melalui analisis faktor, mereka menemukan lima faktor motivasi dan tiga faktor demotivasi. Motivasi pembelajar tidak menunjukkan perubahan yang signifikan terkait dengan masa pengalaman belajar mereka dari kurang setahun sampai lebih dari tiga tahun. Sementara itu, aktualisasi diri menjadi faktor motivasi yang paling berpengaruh, sedangkan beban ujian kelulusan menjadi faktor demotivasi yang dominan. ${ }^{56}$

Kurangnya kepercayaan diri juga menjadi indikator yang disepakati sebagian besar partisipan sebagai salah satu pemicu demotivasi. Terkait hal ini, riset Falout dan Murayama di Jepang menunjukkan bahwa faktor yang mempengaruhi turunnya motivasi siswa dalam mempelajari bahasa asing bisa bersumber dari kurangnya kepercayaan diri, sikap negatif terhadap bahasaasing, materipelajarandanguru.Siswa yang memiliki kemampuan rendah lebih rentan dengan sikap kurangnya kepercayaan diri ini karena berpotensi untuk lebih tidak menyukai bahasa asing dibandingkan siswa yang memiliki kemampuan tinggi. Siswa

56 Riset ini mengeksplorasi faktor motivasi dan demotivasi dalam pembelajaran bahasa Inggris di kalangan pembelajar dewasa yang mengikuti pendidikan di sebuah institut di Seoul, Korea Selatan. Penelitian ini melibatkan 420 pembelajar dewasa dengan pengalaman belajar bahasa Inggris terbatas untuk mengisi kuesioner dengan 47 item yang menggunakan skala Likert (Lihat Tae-Young Kim dan Yoon-Kyoung Kim, "Elderly Korean Learners' Participation in English Learning Through Lifelong Education: Focusingon MotivationandDemotivation," http://www.researchgate/publication/267340987_ Elderly_Korean_Learners\%27_Participation_in_ English_Learning_Through_Lifelong_Education_ Focusing_on_Motivation_and_Demotivation, diakses tanggal 27 April 2015. dengan kemampuan rendah lebih sering terinternalisasi oleh faktor-faktor penyebab demotivasi mereka. ${ }^{57}$

Faktor kemampuan dasar dan pengalaman belajar sebelumnya menempati urutan kedua dalam hal menyebabkan demotivasi siswa. Dari esei singkat yang ditulis siswa partisipan ditemukan sebesar $18,6 \%$ pernyataan yang memuat indikator kemampuan dasar dan pengalaman siswa sebelumnya dalam mempelajari bahasa Arab. Beberapa indikator tersebut masingmasing adalah: 'belum pernah belajar sebelumnya' (10.6\%), 'tidak mengetahui cara mempelajari bahasa Arab' (5.3\%), dan 'kurang percaya diri dalam belajar' (2.7\%). ${ }^{58}$

Berikut ini beberapa pernyataan siswa yang mengindikasikan bahwa faktor kemampuan dasar dan pengalaman belajar sebelumnya dapat menyebabkan penurunan motivasi dalam pembelajaran bahasa Arab, "Saya tidak percaya diri dalam belajar bahasa Arab, karena saya baru belajar bahasa arab dan saya tidak tahu saya bisa atau tidak belajar bahasa Arab."59 Pernyataan lainnya yang menggambarkan hal senada misalnya, "Karena saya baru belajar bahasa Arab itu semenjak SMA saja, jadi seperti saya merasa tergusur. Saya jadi minder melihat atau bersaing di kelas dengan orang yang sudah lama belajar bahasa Arab dan orang yang pengetahuan dalam bidang bahasa Arabnya sudah lebih."60 Demikian juga dengan pernyataan berikut ini, “... saya suka tidak

57 Joseph Falout and Mika Maruyama, "A Comparative Study of Proficiency and Learner Demotivation," The Language Teacher- Issue 28.8; August 2004, http://jalt-publications.org/tlt/ articles /447-comparative-study-proficiency-andlearner-demotivation

58 Lihat lampiran "Analisis Esei Singkat Partisipan."

59 Esei singkat siswa kelas XI IPA, nomor partisipan 004.

${ }^{60}$ Esei singkat siswa kelas XI IPA, nomor partisipan 006. 
paham karena saya alumni dari SMP, jadi belajar bahasa Arab dari nol. ..."61

Faktor kurangnya kepercayaan diri juga menjadi salah satu hal yang dapat menyebabkan munculnya penurunan motivasi. Dalam risetnya, Falout dan kawan-kawan menemukan bahwa para pembelajar bahasa yang fasih membangun kepercayaan dirinya selama proses pembelajaran bahasa asing. Sedangkan para pembelajar bahasa asing yang kurang fasih cenderung mengkritisi dirinya pada saat mereka merasa bahwa keberhasilan dalam berbahasa adalah satu hal yang sulit dicapai. ${ }^{62}$ Dornyei mengidentifikasi kurangnya percaya diri sebagai faktor internal yang disebabkan oleh pengalaman kegagalan dalam merespon elemen eksternal seperti skor atau nilai. ${ }^{63}$

\section{Sikap Negatif terhadap Bahasa Arab}

Pada 2004, Martin Lamb, sebagaimana dikutip Hosseini dan Pourmandnia, melakukan penelitian terhadap motivasi orang Indonesia terhadap pembelajaran bahasa Inggris. Penelitian ini bertujuan untuk melacak perubahan motivasi siswa dan aktivitas pembelajaran mereka serta mengidentifikasi faktor internal atau eksternal yang mungkin terkait dengan perubahan yang terjadi. Riset ini menghasilkan temuan bahwa sikap awal yang sangat positif dari pembelajar terhadap bahasa dan ekspektasi akan keberhasilan adalah dua hal yang perlu dijaga dalam masa pembelajaran, karena sikap mereka terhadap pengalaman belajar formal cenderung negatif. ${ }^{64}$

61 Esei singkat siswa kelas XI Bahasa, nomor partisipan 093.

62 Lihat Joseph Falout, James Elwood dan Michael Hood, "Demotivation: Affective states and learning outcomes," System 37 (2009), 403-417.

63 Ibid.," 405.

64 Lihat Seyyed Behrooz Hosseini dan Delaram
Hasil tabulasi esei singkat siswa mengindikasikan sikap negatif terhadap bahasa Arab hanya berkontribusi sebesar 3,5\% dari keseluruhan pernyataan esei yang direkapitulasi. Pernyataan tersebut muncul dalam empat esei singkat siswa dengan indikator bahwa siswa tidak tertarik untuk belajar bahasa Arab. ${ }^{65}$ Berikut ini adalah contoh dari pernyataan tersebut, "Menurut saya, pelajaran bahasa Arab itu sulit dimengerti, dan saya sangat tidak menyukai pelajaran ini ..."66

\section{Dominasi Faktor Eksternal sebagai Penyebab Demotivasi}

Dari rincian dan penjelasan mengenai faktor-faktor yang dapat menimbulkan demotivasi dalam pembelajaran bahasa Arab di madrasah, diperoleh informasi tentang faktor demotivasi yang dominan dibanding faktor lainnya. Hasil tabulasi penafsiran esei singkat siswa menunjukkan bahwa faktor eksternal lebih mendominasi dalam proses munculnya demotivasi pembelajaran bahasa Arab di madrasah. Dari 113 pernyataan esei yang dapat dianalisis, faktor eksternal berkontribusi sebesar 77,9\%, sementara faktor internal sebesar 22,1\%.

Secara rinci,faktor eksternal berasal dari karakteristik bahasa Arab yang memberikan kontribusi sebesar 49,6\%, lingkungan dan fasilitas belajar sebesar 15,9\% metodologi dan materi pembelajaran sebesar 9,7\%, dan faktor perilaku dan kepribadian guru sebesar 2,7\%. Sementara itu, faktor internal bersumber dari kemampuan dasar dan pengalaman sebelumnya sebesar $18,6 \%$ dan Pourmandnia, "Language Learners' Attitudes and Beliefs: Brief Review of The Related Literature and Frameworks," International Journal on New Trends in Education and Their Implications, October 2013 Volume: 4 Issue: 4, 63-74.

65 Lihat lampiran "Analisis Esei Singkat Partisipan."

66 Esei singkat siswa kelas XI IPS, nomor 058. 
sikap negatif terhadap bahasa Arab sebesar $3,5 \%{ }^{67}$

Lebih lanjut, banyaknya kosakata yang harus dihafal menjadi indikatorkarakteristik bahasa Arab yang berkontribusi besar terhadap munculnya demotivasi pembelajaran bahasa Arab. Sebanyak 23,9\% pernyataan siswa berasal dari indikator ini, ditambah tata bahasa yang sulit $(11,5 \%)$, kebingungan menerjemahkan kata dalam teks $(8,9 \%)$, pengucapan huruf yang sukar $(3,5 \%)$, dan sulitnya mempraktikkan percakapan $(1,8 \%) .^{68}$

Sementara itu, faktor kemampuan dasar dan pengalaman belajar sebelumnya menjadi sisi internal siswa yang memiliki potensi besar dalam menimbulkan demotivasi. Pernyataan bahwa mereka belum pernah belajar sebelumnya mendominasi faktor internal yang satu ini sebesar 9,8\%, selain mereka juga tidak mengetahui cara mempelajari bahasa Arab (6,2\%), kurang percaya diri dalam belajar $(4,6 \%)$ dan hasil belajar yang rendah $(3,1 \%) .{ }^{69}$

Sikap negatif terhadap bahasa Arab serta perilaku dan kepribadian guru menjadi dua faktor yang paling jarang dikemukakan oleh para siswa partisipan. Hanya 3,5\% dari total pernyataan yang menyebutkan bahwa mereka tidak tertarik untuk belajar bahasa Arab. Apalagi dari faktor perilaku dan kepribadian guru hanya ditemukan 2,7\% dari total pernyataan yang dianalisis. Indikator yang terkait dengan perilaku dan kepribadian guru bersumber dari sikap pilih kasih sebanyak (1,8\%) dan tidak bersemangat dalam mengajar $(0,9 \%){ }^{70}$

\footnotetext{
67 Lihat lampiran "Analisis Esei Singkat Partisipan."

68 Lihat lampiran "Analisis Esei Singkat Partisipan."

69 Lihat lampiran "Analisis Esei Singkat Partisipan."

${ }^{70}$ Lihat lampiran "Analisis Esei Singkat Partisipan."
}

Hasil temuan dalam penelitian ini menegaskan riset-riset terdahulu yang menyatakan bahwa munculnya demotivasi dalam pembelajaran bahasa asing lebih disebabkan oleh faktor eksternal. Temuan ini senada dengan hasil penelitian Aladdin pada 2013 di Malaysia yang menyebutkan faktorfaktor demotivasi dalam pembelajaran bahasa Arab bagi nonmuslim. Aladdin menempatkan karak-teristik bahasa Arab sebagai faktor eks-ternal utama penyebab demotivasi. ${ }^{71}$

Sebaliknya, hasil temuan penelitian ini berbeda dengan apa yang dikemukakan oleh Chen melalui penelitiannya di Taiwan pada 2013. Chen menyebutkan bahwa faktor internal yang didominasi oleh kurangnya kepercayaan diri menjadi pemicu utama dalam munculnya demotivasi dalam pembelajaran bahasa asing, khususnya bahasa Inggris. ${ }^{72}$

\section{Simpulan}

Dari paparan mengenai faktor-faktor demotivasi dalam pembelajaran bahasa Arab baik eksternal maupun internal, diperoleh informasi mengenai hal-hal yang dapat menurunkan motivasi siswa dalam mempelajari bahasa Arab. Dalam perspektif siswa madrasah, faktor eksternal yang dapat menyebabkan demotivasi adalah karakteristik bahasa Arab, materi dan metodologi pembelajaran, lingkungan dan fasilitas belajar dan perilaku guru. Sedangkan faktor internal pemicu demotivasi lebih banyak bersumber dari kemampuan dasar siswa dan pengalaman belajar sebelumnya dan juga sikap negatif siswa terhadap bahasa Arab.

Inventarisasi faktor penyebab demotivasi ini dapat dijadikan pijakan

71 Aladdin, op.cit., h. 1655.

72 Chen, op.cit., h. 36. 
awal bagi pihak terkait dalam menentukan langkah-langkah yang dapat ditempuh untuk meningkatkan motivasi siswa dalam mempelajari bahasa Arab di madrasah khususnya.

\section{Daftar Rujukan}

Abdul Wahab, Muhbib. Epistemologi dan Metodologi Pembelajaran Bahasa Arab, Jakarta: Lembaga Penelitian UIN Syarif Hidayatullah, 2008.

Ainin, Moch. "Fenomena Demotivasi dalam Pembelajaran Bahasa Arab di Madrasah: Penyebab dan Alternatif Pemecahannya", pidato pengukuhan guru besar sebagai Guru Besar dalam bidang Pembelajaran Bahasa Arab pada Fakultas Sastra (FS) Universitas Malang (UM), Kamis, 28 April 2011.

Ashinida Aladdin. "Demotivating Factors in the Arabic Language Clasroom: What demotivates non-Muslim Malaysian learners when it comes to learning Arabic?," Procedia-Social and Behavioral Sciences 93 (2013).

Chaer, Abdul. Psikolinguistik: Kajian Teoretik, Jakarta: Rineka Cipta, 2009.

Chen, Pin Yu. "An Analysis of Demotivating Factors among EFL High School Students in Central Taiwan," tesis di Chaoyang University of Technology, 2013.

Direktorat Pendidikan Madrasah Direktorat Jenderal Pendidikan Islam Kementerian Agama RI, Profil Madrasah, Jakarta: Direktorat Pendidikan Madrasah Direktorat Jenderal Pendidikan Islam Kementerian Agama RI, 2014.

Dörnyei, Zoltan dan Ema Ushioda. Teaching and Researching Motivation (2nd ed.), Harlow, England: New York, Longman, 2011.
Fahrurrozi, Aziz dan Erta Mahyudin. Pembelajaran Bahasa Arab, Jakarta: Direktorat Jenderal Pendidikan Islam Kementerian Agama, 2012.

----. Teknik Pembelajaran Bahasa Arab, Bandung: Pustaka Cendekia, 2013.

Falout, Joseph ,James Elwood dan Michael Hood. "Demotivation: Affective states and learning outcomes," System 37 (2009).

Falout, Joseph and Mika Maruyama. "A Comparative Study of Proficiency and Learner Demotivation," The Language Teacher - Issue 28.8; Agustus2004, 3-9. http://jalt-publications.org/ tlt/articles/447-comparative-studyproficiency-and-learner-demotivation

Fattash, Maher M. "Demotivating Factors of University ESL Teachers," International Journal of Humanities and Social Science Vol. 3 No. 19; November 2013.

Gardner, Robert C. "Motivation and Second Language Acquisition," Porta Linguarum 8 (2007).

Hamada, Yo dan Ben Grafstrom. "Demotivating factors in learning Japanese as a foreign language, Akita University 2014.

Hamada, Yo dan Kazuya Kito. "Demotivation in Japanese high schools" in K. BradfordWatts (Ed.), JALT 2007 Conference Proceeding, 2008.

Hosseini, Seyyed Behrooz dan Delaram Pourmandnia. 'Language Learners' Attitudes and Beliefs: Brief Review of The Related Literature and Frameworks,"International Journal on New Trends in Education and Their Implications, Volume: 4 Issue: 4, October 2013. 
Kikuchi, Keita dan Hideki Sakai. "Japanese Learners' Demotivation to Study English: A Survey Study." JALT Journal Vol. 31, No. 2 (2009).

Kim, Tae-Young dan Yoon-Kyoung Kim. 'Elderly Korean Learners' Participation in English Learning Through Lifelong Education: Focusing on Motivation and Demotivation," http: / / www.researchgate.net/ publication/267340987, diakses tanggal 27 April 2015.

Lubis, Maimun Aqsha. "Teaching and Learning Arabic Language through Multicultural Approach and Applying ICT in Pesantren Institution," International Journal of Education and Information Technologies, Issue 3, Volume 3, 2009.

Muhonen, Jenni. "Second Language Demotivation: Factors That Discourage Pupils From Learning The English Language," tesis di University of Jyväskylä, 2004.

Nasution, Sahkholid. "Metode Konvensional dan Inkonvensional dalam Pembelajaran Bahasa Arab", Jurnal Ilmiah DIDAKTIKA Februari 2012 VOL. XII NO. 2.

Peraturan Menteri Agama Republik Indonesia Nomor 90 Tahun 2013 tentang Penyelenggaraan Pendidikan Madrasah.
Sugino, Toshiko. "Teacher demotivational factors in the Japanese language teaching context," Procedia Social and Behavioral Sciences 3 (2010).

Sukmadinata, Nana Syaodih. Metode Penelitian Pendidikan, Bandung: Remaja Rosdakarya, 2005.

Tabatabaei, Omid dan Ahmad Molavi. "Demotivating Factors Affecting EFL Learning of Iranian Seminary Students," International Education Studies Vol. 5, No. 1 (2012).

Taguchi, Naoko. "The Role of Learning Environment in The Development of Pragmatic Comprehension: A Comparison of Gains Between EFL and ESL Learners", SSLA, 30, 2008.

Thomas, Irving. "How Hard is Arabic" The Modern Language Journal, Vol 41, No.6 Oktober 1957.

Tinsley, Teresa dan Kathryn Board. Languages for the Future: Which Languages the UK Needs Most and Why, British Council, 2013.

Yaakub, Muhamadul Bakir Hj. "A field observation on the philosophy of teaching Islamic and Arabic studies," US-China Education Review, Volume 6, No.3 (Serial No.52), Mar. 2009. 


\section{Lampiran}

\section{Analisis Esei Singkat Partisipan}

\begin{tabular}{|c|c|c|}
\hline Faktor 1: Karakteristik Bahasa Arab & $49.6 \%$ & 56 \\
\hline - $\quad$ Terlalu banyak kosakata & $23.9 \%$ & 27 \\
\hline - $\quad$ Tata bahasa Arab yang sulit & $11.5 \%$ & 13 \\
\hline - $\quad$ Bingung menerjemahkan kata dalam teks & $8.9 \%$ & 10 \\
\hline - $\quad$ Pengucapan huruf yang sukar & $3.5 \%$ & 4 \\
\hline - $\quad$ Sulitnya mempraktikkan percakapan & $1.8 \%$ & 2 \\
\hline $\begin{array}{l}\text { Faktor 2: Kemampuan Dasar dan Pengalaman } \\
\text { sebelumnya }\end{array}$ & $18.6 \%$ & 21 \\
\hline - $\quad$ Belum pernah belajar sebelumnya & $10.6 \%$ & 12 \\
\hline - $\quad$ Tidak tahu cara mempelajari bahasa Arab & $5.3 \%$ & 6 \\
\hline - $\quad$ Kurang percaya diri dalam belajar & $2.7 \%$ & 3 \\
\hline Faktor 3: Lingkungan dan Fasilitas Belajar & $15.9 \%$ & \\
\hline - Waktu belajar yang tidak sesuai & $10.6 \%$ & 12 \\
\hline - $\quad$ Perilaku teman yang mengganggu & $3.5 \%$ & 4 \\
\hline - Jumlah rombel yang banyak & $1.8 \%$ & 2 \\
\hline Faktor 4: Metodologi dan Materi Pembelajaran & $9.7 \%$ & 11 \\
\hline - $\quad$ Metode pembelajaran yang monoton & $8.9 \%$ & 10 \\
\hline - $\quad$ Kurang kerja kelompok & $0.8 \%$ & 1 \\
\hline Faktor 5: Sikap Negatif terhadap Bahasa Arab & $3.5 \%$ & 4 \\
\hline - $\quad$ Tidak tertarik untuk belajar bahasa Arab & $3.5 \%$ & 4 \\
\hline Faktor 6: Perilaku dan Kepribadian Guru & $2.7 \%$ & 3 \\
\hline - $\quad$ Sikap pilih kasih & $1.8 \%$ & 2 \\
\hline - $\quad$ Tidak bersemangat dalam mengajar & $0.9 \%$ & 1 \\
\hline Total & $100.0 \%$ & 113 \\
\hline
\end{tabular}

